\title{
HEALING THE FRONTIER: \\ CATHOLIC SISTERS, HOSPITALS, AND MEDICINE MEN \\ IN THE WISCONSIN BIG WOODS, 1880-1920
}

\author{
Kirstin L. Lawson \\ Dr. Catherine Rymph, Dissertation Supervisor
}

\begin{abstract}
This dissertation examines Gilded Age and Progressive Era frontier American images of health and sickness as well as the development and application of an early modern doctrine of health care. I do this through an examination of the archived history of Hayward, Wisconsin, as well as through an examination of the recorded experiences of the Ojibwa who lived on the Lac Courte Oreilles (LCO) reservation, about fifteen miles south of Hayward. The population on the LCO held intricate ties with the people of Hayward; those ties were legal and social, religious and secular, cultural and political. In sickness and in health, the fortunes of Haywardites were united with the fates of the LCO Ojibwa. Because of these ties with a population so dissimilar to mainstream America, a trouble-free advent of the cannon of modern public health care was not a foregone conclusion in Hayward, nor was the development of a modern definition of health or sickness inevitable. At critical moments, individual Haywardites or Ojibwa made decisions that led the community to its eventual profession of faith in modern American health care.
\end{abstract}

